\title{
Catalytic Hydroamination of Alkynes and Norbornene with Neutral and Cationic Tantalum Imido Complexes
}

\author{
Laura L. Anderson, John Arnold", Robert G. Bergman* \\ Department of Chemistry, University of California Berkeley, Berkeley, California, 94720 \\ Supporting Information
}

General Information. All reactions and manipulations, unless otherwise noted, were carried out in an inert atmosphere $\left(\mathrm{N}_{2}\right)$ glovebox at $10{ }^{\circ} \mathrm{C}$ or using standard Schlenk and high vacuum techniques. All glassware was dried in an oven at $150{ }^{\circ} \mathrm{C}$ for at least $12 \mathrm{~h}$ prior to use or was flame dried under reduced pressure. Magnetic stirring was used when necessary. Pentane, hexane, diethyl ether, benzene, toluene, and methylene chloride were dried and purified by passage through a column of activated alumina under $\mathrm{N}_{2}$ pressure, sparging with $\mathrm{N}_{2}$ and storage over $4 \cdot$ sieves. $^{1}$ Fluorobenzene, aniline, 2,6-dimethylaniline, 1pentyne, 2-hexyne, 3-hexyne, 1-phenylpropyne, and phenylacetylene (Aldrich) were distilled from $\mathrm{CaH}_{2}$ prior to use and were stored over $4 \bullet$ molecular sieves. Toluidine, anisidine and $p$-chloroaniline (Aldrich) were crystallized from hot hexane prior to use. Diphenylacetylene (Aldrich) was sublimed. Norbornene (Aldrich) was vacuum transferred. $\mathrm{PhCH}_{2} \mathrm{MgCl},\left(\mathrm{CH}_{3}\right)_{3} \mathrm{CCH}_{2} \mathrm{MgCl}$, deoxybenzoin, 2-pentanone, 2hexanone, 3-hexanone, acetophenone and methylbenzylketone (Aldrich), as well as $\mathrm{Ta}\left(\mathrm{NMe}_{2}\right)_{5}(\mathrm{Strem})$ and allene (Matheson) were purchased and used without further purification. Compound 1,2 $\mathrm{Ph}_{3} \mathrm{CB}\left(\mathrm{C}_{6} \mathrm{~F}_{5}\right)_{4},{ }^{3}$ and cyclonona-1,2-diene 4 were prepared according to published protocols. Deuterated

\footnotetext{
1 Alaimo, P. J.; Peters, D. W.; Arnold, J.; Bergman, R. G. J. Chem. Ed. 2001, 78, 64.

2 Sundermeyer, J.; Putterlik, J.; Foth, M.; Field, J. S.; Ramesar, N. Chem. Ber. 1994, 127, 1201-1212.

${ }^{3}$ Lambert, J. B.; Zhang, S. Z.; Ciro, S. M. Organometallics 1994, 13, 2430-2443.
} 
solvents were purchased from Cambridge Isotope Laboratories. Benzene- $d_{6}$ was vacuum transferred from purple $\mathrm{Na}$ /benzophenone and degassed with 3 freeze-evacuation-thaw cycles. Toluene- $d_{8}$ and chlorobenzene- $d_{5}$ were vacuum transferred from $\mathrm{CaH}_{2}$ and degassed with 3 freeze-evacuation-thaw cycles. For non-air sensitive samples benzene- $d_{6}$ and chloroform- $d$ were used from the supplier without further purification. ${ }^{1} \mathrm{H},{ }^{2} \mathrm{H},{ }^{13} \mathrm{C}$, spectra were recorded on Bruker AVQ-400 (400 MHz), AV-400 (400 MHz), and DRX-500 (500 MHz) spectrometers as indicated. ${ }^{1} \mathrm{H}$ NMR chemical shifts $(\delta)$ are reported in parts per million (ppm) relative to residual protiated solvent $\left(\mathrm{CDCl}_{3}, 7.25 ; \mathrm{C}_{6} \mathrm{D}_{6}, 7.15 ; \mathrm{C}_{7} \mathrm{D}_{8}, 2.1\left(\mathrm{CH}_{3}\right) ; \mathrm{C}_{6} \mathrm{D}_{5} \mathrm{Cl}, 6.99\right.$ $(o-\mathrm{CH})$ ) or an external standard of $\mathrm{CH}_{2} \mathrm{Cl}_{2}$ in $\mathrm{C}_{6} \mathrm{D}_{6}$ (4.42). Data are reported as follows: $(\mathrm{s}=$ singlet, $\mathrm{d}=$ doublet, $\mathrm{t}=$ triplet, $\mathrm{q}=$ quartet, $\mathrm{m}=$ multiplet; coupling constant(s) in Hz; integration; assignment). Chemical shifts were assigned with the aid of DEPT 45, 90 and 135 experiments as well as HMQC, TOCSY, NOESY and HMBC where necessary. Reactions with allene were performed by condensation of a measured pressure of $\mathrm{C}_{3} \mathrm{H}_{4}$ from a bulb of known volume into an NMR tube at $-196{ }^{\circ} \mathrm{C}$. The pressure was determined using a digital MKS Baratron gauge attached to a high vacuum line. Merck silica gel, 60 $\AA$ A, 230-400 mesh, grade 9385 was used in chromatography unless otherwise noted. Gas ChromatographMass Spectroscopy (GC-MS) data were obtained using an Agilent Technologies Instrument 6890N GC (column \#HP-5MS, 30.0m x 250 $\mathrm{m}$ x $0.25 \mu \mathrm{m}$ calibrated) and 5973N MS. Elemental analyses were performed at the UC-Berkeley Microanalytical facility with a Perkin Elmer 2400 Series II CHNO/S Analyzer.

$\left(\mathbf{P h C H}_{2}\right)_{3} \mathbf{T a}=\mathrm{NCMe}_{3}(\mathbf{1 a}):$ To a slurry of $(\text { py })_{2} \mathrm{Cl}_{3} \mathrm{Ta}=\mathrm{NCMe}_{3}(3.51 \mathrm{~g}, 6.79 \mathrm{mmol}, 1.0$ equiv $)$ at $-78{ }^{\circ} \mathrm{C}$ in $\mathrm{Et}_{2} \mathrm{O}(200 \mathrm{~mL})$ was added $\mathrm{PhCH}_{2} \mathrm{MgCl}\left(1.0 \mathrm{M}_{\text {in }} \mathrm{Et}_{2} \mathrm{O}, 20.4 \mathrm{~mL}, 20.40 \mathrm{mmol}, 3.0\right.$ equiv). The reaction mixture was covered with aluminum foil and allowed to warm to $25{ }^{\circ} \mathrm{C}$ and stir for $8 \mathrm{~h}$ in the absence of light. Volatile materials were removed under reduced pressure to give a light yellow solid which was

${ }^{4}$ Skattebol, L.; Solomon, S. Org. Synth. 1969, 49, 35. Shea, K. J.; Kim, J. S. J. Am. Chem. Soc. 1992, 114, 3044-3051. 
extracted with toluene $(150 \mathrm{~mL})$. The toluene solution was separated from the remaining $\mathrm{MgCl}_{2}$ by cannula filtration. Toluene was removed under reduced pressure to give 1a as a bright yellow solid (2.68 g, $5.10 \mathrm{mmol}, 75 \%) .{ }^{1} \mathrm{H}$ NMR $\left(\mathrm{C}_{6} \mathrm{D}_{6}, 500 \mathrm{MHz}\right) \delta 7.02(\mathrm{~m}, 9 \mathrm{H}, \mathrm{ArH}), 6.68(\mathrm{~m}, 6 \mathrm{H}, \mathrm{ArH}), 1.66(\mathrm{~s}, 6 \mathrm{H}$, $\left.\mathrm{CH}_{2} \mathrm{Ph}\right), 1.39\left(\mathrm{~s}, 9 \mathrm{H}, \mathrm{CMe}_{3}\right) .{ }^{13} \mathrm{C}\left\{{ }^{1} \mathrm{H}\right\}$ NMR $\left(\mathrm{C}_{6} \mathrm{D}_{6}, 125 \mathrm{MHz}\right) \delta$ 136.4, 130.1, 129.9, and $125.7 \mathrm{ArC}, 67.9$ $\left(\mathrm{CMe}_{3}\right), 67.6\left(\mathrm{CH}_{2} \mathrm{Ph}\right), 33.1\left(\mathrm{CMe}_{3}\right)$. Anal. Calcd. C, 57.15; H, 5.76; N, 2.67. Found C, 57.46; H, 5.97; N, 2.65 .

$\left(\mathrm{Me}_{3} \mathbf{C C C H}_{2}\right)_{3} \mathbf{T a}=\mathrm{NCMe}_{3}(\mathbf{1 b}):$ To a $10{ }^{\circ} \mathrm{C}$ slurry of $(\mathrm{py})_{2} \mathrm{Cl}_{3} \mathrm{Ta}=\mathrm{NCMe}_{3}(426 \mathrm{mg}, 0.825 \mathrm{mmol}, 1.0$ equiv) in $\mathrm{Et}_{2} \mathrm{O}(15 \mathrm{~mL})$ was added $\mathrm{Me}_{3} \mathrm{CCH}_{2} \mathrm{MgCl}\left(1.0 \mathrm{M}\right.$ in $\mathrm{Et}_{2} \mathrm{O}, 2.5 \mathrm{~mL}, 2.5 \mathrm{mmol}, 3.0$ equiv). The reaction mixture was covered with aluminum foil and allowed to stir for $8 \mathrm{~h}$ in the absence of light. Volatile materials were removed under reduced pressure to give an off-white solid which was extracted with hexane $(15 \mathrm{~mL})$. The hexane solution was separated from the remaining $\mathrm{MgCl}_{2}$ by filtration through a pipet containing a glass fiber filter. Hexane was then removed under reduced pressure to give off-white 1 b $(294 \mathrm{mg}, 0.631 \mathrm{mmol}, 76 \%)$. ${ }^{1} \mathrm{H}$ NMR $\left(\mathrm{C}_{6} \mathrm{D}_{6}, 500 \mathrm{MHz}\right) \delta 1.62(\mathrm{~s}, 9 \mathrm{H}, \mathrm{CMe}), 1.14(\mathrm{~s}, 27 \mathrm{H}$, $\left.\mathrm{CH}_{2} \mathrm{CMe}_{3}\right), 0.81\left(\mathrm{~s}, 6 \mathrm{H}, \mathrm{CH}_{2} \mathrm{CMe}_{3}\right) .{ }^{13} \mathrm{C}\left\{{ }^{1} \mathrm{H}\right\} \operatorname{NMR}\left(\mathrm{C}_{6} \mathrm{D}_{6}, 125 \mathrm{MHz}\right) \delta 108.2\left(\mathrm{CH}_{2} \mathrm{CMe}_{3}\right), 68.3\left(\mathrm{CMe}_{3}\right)$, $35.3\left(\mathrm{CH}_{2} \mathrm{CMe} e_{3}\right), 35.1\left(\mathrm{CH}_{2} \mathrm{CMe}_{3}\right), 34.3\left(\mathrm{CMe}_{3}\right)$. Anal. Calcd. C, 49.03; H, 9.10; N, 3.00. Found C, 49.27; H, 9.15; N, 3.01 .

$\left(\mathbf{E t}_{2} \mathbf{N}\right)_{3} \mathbf{T a}=\mathrm{NCMe}_{3}$ : To a $10{ }^{\circ} \mathrm{C}$ slurry of $(\mathrm{py})_{2} \mathrm{Cl}_{3} \mathrm{Ta}=\mathrm{NCMe}_{3}(1.77 \mathrm{~g}, 3.42 \mathrm{mmol}, 1.0$ equiv $)$ in $\mathrm{Et}_{2} \mathrm{O}$ $(15 \mathrm{~mL})$ was added $\mathrm{LiNEt}_{2}(813 \mathrm{mg}, 10.3 \mathrm{mmol}, 3$ equiv $)$. The reaction mixture was covered with aluminum foil and allowed to stir for $8 \mathrm{~h}$ in the absence of light. Volatile materials were removed under reduced pressure to give a brown solid which was extracted with hexane $(15 \mathrm{~mL})$. The hexane solution was separated from the remaining $\mathrm{MgCl}_{2}$ by filtration through a pipet containing a glass fiber filter. Hexane was then removed under reduced pressure to give a brown oil, $\left(\mathrm{Et}_{2} \mathrm{~N}\right)_{3} \mathrm{Ta}=\mathrm{NCMe}_{3}(1.14 \mathrm{~g}, 2.43$ mmol, $71 \%$ ). ' ${ }^{1} \mathrm{H}\left(\mathrm{C}_{6} \mathrm{D}_{6}, 500 \mathrm{MHz}\right) \delta 3.47$ (q, $\left.J=7.0 \mathrm{~Hz}, 12 \mathrm{H}, \mathrm{CH}_{2}\right), 1.43$ (s, 9H, CMe $), 1.14$ (t, $J=7 \mathrm{~Hz}$, $\left.18 \mathrm{H}, \mathrm{CH}_{3}\right) .{ }^{13} \mathrm{C}\left\{{ }^{1} \mathrm{H}\right\}\left(\mathrm{C}_{6} \mathrm{D}_{6}, 500 \mathrm{MHz}\right) \delta 66.0\left(\mathrm{CMe}_{3}\right), 47.4\left(\mathrm{CH}_{2}\right), 34.3\left(\mathrm{CMe}_{3}\right), 17.0\left(\mathrm{CH}_{3}\right)$.

Preparation of cationic metallacycle 3: To a $10{ }^{\circ} \mathrm{C}$ solution of $\left(\mathrm{PhCH}_{2}\right)_{3} \mathrm{Ta}=\mathrm{NCMe}_{3}(114 \mathrm{mg}, 0.217$ mmol, 1.0 equiv) in fluorobenzene (10 mL) were added diphenylacetylene ( $39 \mathrm{mg}, 0.22 \mathrm{mmol}, 1.0$ equiv) and $\mathrm{Ph}_{3} \mathrm{CB}\left(\mathrm{C}_{6} \mathrm{~F}_{5}\right)_{4}(201 \mathrm{mg}, 0.217 \mathrm{mmol}, 1.0$ equiv). The dark red homogeneous reaction mixture was 
allowed to stand for $20 \mathrm{~min}$ at which time volatile materials were removed under reduced pressure to give a dark red oil. The oil was shaken with benzene $(10 \mathrm{~mL})$ to form a cloudy suspension which was layered with hexane $(5 \mathrm{~mL})$ and allowed to sit at $10{ }^{\circ} \mathrm{C}$ for $30 \mathrm{~min}$. During this time a dark red oil precipitated. The solution was decanted and the oil was triturated with $3 \times 5 \mathrm{~mL}$ portions of pentane to give a red foam (96 mg, $0.074 \mathrm{mmol}, 34 \%)$. ${ }^{1} \mathrm{H} \mathrm{NMR}\left(\mathrm{C}_{6} \mathrm{D}_{5} \mathrm{Cl}, 500 \mathrm{MHz}\right) \delta 7.22-7.19(\mathrm{~m}, 3 \mathrm{H}, \mathrm{ArH}), 7.06-7.00$ (m, 5H, $\operatorname{ArH}), 6.85-6.76(\mathrm{~m}, 10 \mathrm{H}, \operatorname{Ar} H), 6.70,6.63(\mathrm{t}, J=6.5 \mathrm{~Hz}, 1 \mathrm{H}, \mathrm{ArH}), 6.54(\mathrm{t}, J=6.5 \mathrm{~Hz}, 4 \mathrm{H}, \operatorname{Ar} H), 6.02(\mathrm{t}$, $J=7.5 \mathrm{~Hz}, 1 \mathrm{H}, p$-ArH of $\eta^{2}$-benzyl ligand), 3.62 (d, $\left.J=17.0 \mathrm{~Hz}, 1 \mathrm{H}, \mathrm{CHHPh}\right), 3.48$ (d, $J=17.0 \mathrm{~Hz}, 1 \mathrm{H}$, $\mathrm{CHHPh}), 2.86(\mathrm{~d}, J=11.5 \mathrm{~Hz}, 1 \mathrm{H}, \mathrm{CHHPh}), 2.17$ (d, J = 11.5 Hz, 1H, CHHPh), 0.881 (s, 9H, CMe $)$. ${ }^{13} \mathrm{C}\left\{{ }^{1} \mathrm{H}\right\}\left(\mathrm{C}_{6} \mathrm{D}_{5} \mathrm{Cl}, 500 \mathrm{MHz}\right) \delta 208.0$ (ipso-C of $\eta^{2}$-benzyl), $173.1(\mathrm{NC}(\mathrm{Ph}) \mathrm{C}$ ), 152.0 (ipso-C of the phenyl group attached to the $\mathrm{C}$ at $173.1 \mathrm{ppm}), 143.9(\mathrm{TaCPh}), 140.2$ (ipso- $C$ of the phenyl group attached to the $\mathrm{C}$ at $143.9 \mathrm{ppm}), 149.5,147.6,137.4,135.5,134.7$ (b, $\operatorname{ArC}-\mathrm{F}), 134.3,133.8,131.4,129.7,129.6$, 126.5, 126.3, 121.6, 120.5 (other ArC resonances, remaining resonances are obscured by solvent), 73.2, $46.0\left(\mathrm{CH}_{2} \mathrm{Ph}\right), 69.2\left(\mathrm{CMe}_{3}\right), 31.9\left(\mathrm{CMe}_{3}\right)$. Anal. Calcd. C, 52.08; H, 2.58; N, 1.08. Found C, 51.93; H, $2.78 ; \mathrm{N}, 1.25$.

Preparation of an authentic imine sample: N-1,2-diphenylethylidene aniline. Compound 4. A $250 \mathrm{~mL}$ round bottom flask was charged with deoxybenzoin $(7.27 \mathrm{~g}, 37.0 \mathrm{mmol}, 1$ equiv), aniline (15.3 g, $165 \mathrm{mmol}, 4.4$ equiv), $p$-toluenesulfonic acid $(721 \mathrm{mg})$ and $100 \mathrm{~mL}$ of toluene on the bench top. The flask was attached to a Dean-Stark trap and heated at reflux for $24 \mathrm{~h}$ under $\mathrm{N}_{2}$. Upon cooling, the reaction mixture was washed with sat. $\mathrm{NaHCO}_{3}$. The organic layer was separated, dried with $\mathrm{MgSO}_{4}$, and filtered. Volatile materials were removed under reduced pressure to give a bright yellow solid (7.28 g, $26.8 \mathrm{mmol}$, 72\%). ${ }^{1} \mathrm{H}$ NMR analysis indicated that approximately $10 \%$ of the sample was unreacted aniline. The yellow solid was crystallized in small batches from $\mathrm{Et}_{2} \mathrm{O}$ at $-35{ }^{\circ} \mathrm{C}$ as needed to give clean imine. ${ }^{1} \mathrm{H}$ NMR $\left(\mathrm{C}_{6} \mathrm{D}_{5} \mathrm{Cl}, 400 \mathrm{MHz}\right) \delta 7.87(\mathrm{~m}, 2 \mathrm{H}, \mathrm{ArH}), 7.04(\mathrm{~m}, 5 \mathrm{H}, \mathrm{ArH}), 6.86(\mathrm{~m}, 6 \mathrm{H}, \mathrm{ArH}), 6.72(\mathrm{~d}, 2 \mathrm{H}, J=$

5 Pindalo, G. J.; Thornton-Pett, M.; Hursthouse, M. B.; Coles, S. J.; Bochmann, M. J. Chem. Soc., Dalton Trans., 1999, 1663-1668. Bochmann, M.; Lancaster, S. J. Organometallics, 1993, $12,633$. Bochmann, M.; Lancaster, S. J.; Hursthouse, M. B.; Malik, K. M. A. Organometallics, 1994, 13, 2235. 
$7.2 \mathrm{~Hz}, \mathrm{ArH}), 3.96\left(\mathrm{~s}, 2 \mathrm{H}, \mathrm{CH}_{2} \mathrm{Ph}\right) .{ }^{13} \mathrm{C}\left\{{ }^{1} \mathrm{H}\right\}$ NMR $\left(\mathrm{C}_{6} \mathrm{D}_{6}, 500 \mathrm{MHz}\right) \delta 199.1$ (imine $C$ ), 165.5, 151.9, $138.6,137.8,130.5,129.3,128.9,128.6,128.5,126.4,123.6,119.3(\mathrm{ArC}), 36.1\left(\mathrm{CH}_{2} \mathrm{Ph}\right)$.

Conversion of N-1,2-diphenyl-ethylidene aniline to an equilibrium mixture of imine and enamine. Compound 5. An NMR tube was charged with approximately $20 \mathrm{mg}$ of 4 and $0.5 \mathrm{~mL}$ of $\mathrm{C}_{6} \mathrm{D}_{5} \mathrm{Cl}$. The tube was flame-sealed and placed in a $135{ }^{\circ} \mathrm{C}$ oil bath for $12 \mathrm{~h}$. Analysis by ${ }^{1} \mathrm{H}$ NMR spectroscopy showed a 3:1 ratio of imine to enamine. ${ }^{1} \mathrm{H}$ NMR of imine $\left(\mathrm{C}_{6} \mathrm{D}_{5} \mathrm{Cl}, 400 \mathrm{MHz}\right) \delta 7.87(\mathrm{~m}$, 2H, $\operatorname{ArH}), 7.04(\mathrm{~m}, 5 \mathrm{H}, \mathrm{ArH}), 6.86(\mathrm{~m}, 6 \mathrm{H}, \mathrm{ArH}), 6.72(\mathrm{~d}, 2 \mathrm{H}, J=7.2 \mathrm{~Hz}, \mathrm{ArH}), 3.96\left(\mathrm{~s}, 2 \mathrm{H}, \mathrm{CH}_{2} \mathrm{Ph}\right) .{ }^{1} \mathrm{H}$ NMR of enamine $\left(\mathrm{C}_{6} \mathrm{D}_{5} \mathrm{Cl}, 400 \mathrm{MHz}\right) \delta 7.37(\mathrm{~m}, 2 \mathrm{H}, \mathrm{Ar} H), 7.24(\mathrm{~m}, 4 \mathrm{H}, \mathrm{ArH}), 6.54(\mathrm{t}, J=8 \mathrm{~Hz}, 2 H$, $\operatorname{ArH}) 6.41(\mathrm{~d}, J=8 \mathrm{~Hz}, 2 \mathrm{H}, \mathrm{ArH})$, (all other aryl enamine resonances overlap with imine aryl resonances), $6.02(\mathrm{~s}, 1 \mathrm{H}, H \mathrm{C}(\mathrm{NHPh})), 5.46(\mathrm{~s}, 1 \mathrm{H}, \mathrm{NH}), 3.88(\mathrm{~s}, 1 \mathrm{H}, \mathrm{CHPh})$. Enamine resonances were similar to those of the analogous N-2,6-dimethylphenyl enamine. ${ }^{6}$

Representative procedures for alkyne and allene hydroamination reactions. In the glovebox, a vial was charged with $4 \mathrm{mg}$ of $\mathbf{1 b}\left(0.0086 \mathrm{mmol}, 1\right.$ equiv) and approximately $0.5 \mathrm{~mL}$ of $\mathrm{C}_{6} \mathrm{D}_{5} \mathrm{Cl}$ (benzene$d_{6}$ and toluene- $d_{8}$ were also used for these reactions but $\mathrm{C}_{6} \mathrm{D}_{5} \mathrm{Cl}$ gave better resolution of product ${ }^{1} \mathrm{H}$ NMR resonances.) To the resulting solution was added the alkyne or allene substrate (0.172 mmol, 20 equiv) and the amine $(0.172 \mathrm{mmol}, 20$ equiv). The reaction mixture was transferred into an NMR tube, which was further charged with a capillary tube containing a solution of $\mathrm{CH}_{2} \mathrm{Cl}_{2} / \mathrm{C}_{6} \mathrm{D}_{6}$. The $\mathrm{NMR}$ tube was then fitted with a Cajon ${ }^{\mathrm{TM}}$ adaptor, removed from the glovebox, and flame sealed under static vacuum. An initial ${ }^{1} \mathrm{H}$ NMR spectrum of the reaction mixture was measured, following which the tube was placed in a $135{ }^{\circ} \mathrm{C}$ oil bath and monitored periodically. Hydroamination reactions with $\mathbf{2}$ were performed in a similar manner: catalyst 2 was generated in situ by dissolving $4 \mathrm{mg}$ of $\mathbf{1 a}\left(0.0076 \mathrm{mmol}, 1\right.$ equiv) in $\mathrm{C}_{6} \mathrm{D}_{5} \mathrm{Cl}$ followed by addition of (in order) the alkyne or allene substrate (0.152 mmol, 20 equiv), $\mathrm{Ph}_{3} \mathrm{CB}\left(\mathrm{C}_{6} \mathrm{~F}_{5}\right)_{4}$ (7.0 $\mathrm{mg}, 0.0076 \mathrm{mmol}, 1$ equiv), and the amine ( $0.152 \mathrm{mmol}, 20$ equiv). The preliminary hydroamination reactions with isolated $\mathbf{2}$ and $\mathbf{3}$ were also carried out similarly by combining the catalyst first with the

${ }^{6}$ Walsh, P. J.; Baranger, A. M.; Bergman, R. G. J. Am. Chem. Soc., 1992, 114, 1708-1719. 
substrate and then with the aniline. For larger scale reactions $20 \mathrm{mg}$ of catalyst was used with $3 \mathrm{~mL}$ of benzene. All reagents were combined in the same order and transferred to a teflon sealed Schlenk flask.

${ }^{1}$ H NMR data for alkyne hydroamination reactions. Yields were determined by NMR integrations versus an external $\mathrm{CH}_{2} \mathrm{Cl}_{2} / \mathrm{C}_{6} \mathrm{D}_{6}$ standard.

Hydroamination of diphenylacetylene with isolated 2: Yield, 26\%. Imine to enamine ratio, 3:1. ${ }^{1} \mathrm{H}$ NMR resonances for the imine and enamine matched authentic samples, $\mathbf{4}$ and $\mathbf{5}$.

Hydroamination of diphenylacetylene with isolated 3: Yield, 28\%. Imine to enamine ratio, 3:1. ${ }^{1} \mathrm{H}$ NMR resonances for the imine and enamine matched authentic samples, 4 and $\mathbf{5}$.

Table 1, entries 1-5. All yields were $>95 \%$. All ${ }^{1} \mathrm{H}$ NMR resonances for the imine and enamine matched authentic samples, $\mathbf{4}$ and $\mathbf{5}$. Imine to enamine ratios were 3:1.

Table 1, entry 6. No reaction was observed by ${ }^{1} \mathrm{H}$ NMR spectroscopy.

Table 2, entry 1: Yield $>95 \%$ with $\mathbf{1 b}$ and 2. Both imine isomers were observed in a 1:1 ratio. ${ }^{1} \mathrm{H}$ NMR $\left(\mathrm{C}_{6} \mathrm{D}_{5} \mathrm{Cl}, 400 \mathrm{MHz}\right) \delta 7.07(\mathrm{t}, J=7.6 \mathrm{~Hz}, 2 \mathrm{H}, \mathrm{Ar} H), 6.80(\mathrm{~m}, 1 \mathrm{H}, \operatorname{Ar} H), 6.55(\mathrm{~d}, J=7.6 \mathrm{~Hz}, 2 \mathrm{H}, \operatorname{Ar} H)$, $2.13\left(\mathrm{~m}, 4 \mathrm{H}, \mathrm{CH}_{2}\right), 1.85\left(\mathrm{~m}, 4 \mathrm{H}, \mathrm{CH}_{2}\right), 1.56$ (q, $\left.J=7.6 \mathrm{~Hz}, 2 \mathrm{H}, \mathrm{CH}_{2}\right), 1.17$ (q, J=7.6 Hz, 2H, $\mathrm{CH}_{2}$ ), 1.05 $\left(\mathrm{t}, J=7.2 \mathrm{~Hz}, 3 \mathrm{H}, \mathrm{CH}_{3}\right), 0.82\left(\mathrm{t}, J=7.2 \mathrm{~Hz}, 3 \mathrm{H}, \mathrm{CH}_{3}\right), 0.69\left(\mathrm{t}, J=7.2 \mathrm{~Hz}, 3 \mathrm{H}, \mathrm{CH}_{3}\right), 0.51(\mathrm{t}, J=7.2 \mathrm{~Hz}$, $\left.3 \mathrm{H}, \mathrm{CH}_{3}\right)$.

Table 2, entry 2: Yield $>95 \%$ with $\mathbf{1 b}$ and $71 \%$ with $\mathbf{2}$. The same two imine isomers as Table 2, entry 1 were observed in a 1:1 ratio with each other and a 1:1 ratio with the other possible imine regioisomer. ${ }^{1} \mathrm{H}$ NMR $\left(\mathrm{C}_{6} \mathrm{D}_{5} \mathrm{Cl}, 400 \mathrm{MHz}\right) \delta 6.92(\mathrm{t}, J=7.6 \mathrm{~Hz}, 1 \mathrm{H}, \mathrm{Ar} H), 6.82(\mathrm{~m}, 2 \mathrm{H}, \operatorname{Ar} H), 6.35(\mathrm{~d}, J=8 \mathrm{~Hz}, 2 \mathrm{H}$, $\mathrm{ArH}), 1.49\left(\mathrm{~m}, 2 \mathrm{H}, \mathrm{CH}_{2}\right), 1.44\left(\mathrm{~s}, 3 \mathrm{H}, \mathrm{CH}_{3}\right), 0.75\left(\mathrm{~m}, 2 \mathrm{H}, \mathrm{CH}_{2}\right), 0.75\left(\mathrm{~m}, 3 \mathrm{H}, \mathrm{CH}_{3}\right)$.

Table 2, entry 3: Yield, $77 \%$ with 1b and $66 \%$ with 2. Only the Markovnikov product was observed. ${ }^{1} \mathrm{H}$ NMR $\left(\mathrm{C}_{6} \mathrm{D}_{5} \mathrm{Cl}, 400 \mathrm{MHz}\right) \delta 7.79(\mathrm{~m}, 2 \mathrm{H}, \mathrm{ArH}), 7.12-6.82(\mathrm{bm}, 6 \mathrm{H}, \mathrm{Ar} H), 6.61(\mathrm{~d}, J=8 \mathrm{~Hz}, 2 \mathrm{H}, \operatorname{Ar} H)$, $1.82\left(\mathrm{~s}, 3 \mathrm{H}, \mathrm{CH}_{3}\right)$.

Table 2, entry 4: Yield, $70 \%$ with 1b and 62\% with 2. Only the Markovnikov product was observed. ${ }^{1} \mathrm{H}$ NMR $\left(\mathrm{C}_{6} \mathrm{D}_{5} \mathrm{Cl}, 400 \mathrm{MHz}\right) \delta 7.07(\mathrm{t}, J=8 \mathrm{~Hz}, 2 \mathrm{H}, \mathrm{ArH}), 6.81(\mathrm{t}, J=7.6,1 \mathrm{H}, \mathrm{ArH}), 6.54(\mathrm{~d}, J=8 \mathrm{MHz}$, 2H, $\mathrm{ArH}), 2.07\left(\mathrm{t}, J=7.2 \mathrm{~Hz}, 3 \mathrm{H}, \mathrm{CH}_{2}\right), 1.50\left(\mathrm{~m}, 2 \mathrm{H}, \mathrm{CH}_{2}\right), 1.46\left(\mathrm{~s}, 3 \mathrm{H}, \mathrm{CH}_{3}\right), 0.79(\mathrm{t}, J=7.2 \mathrm{~Hz}, 3 \mathrm{H}$, $\mathrm{CH}_{3}$ ). 
Table 2, entry 5: Yield, $19 \%$ for 2. No reaction with 1b. Only the anti-Markovnikov product was observed. ${ }^{1} \mathrm{H}$ NMR $\left(\mathrm{C}_{6} \mathrm{D}_{5} \mathrm{Cl}, 400 \mathrm{MHz}\right) \delta$ 7.32-7.01 (bm, 10H, ArH), $3.59\left(\mathrm{~s}, 2 \mathrm{H}, \mathrm{CH}_{2}\right), 1.55(\mathrm{~s}, 3 \mathrm{H}$, $\left.\mathrm{CH}_{3}\right)$.

Table 3, entry 1: Yield, $98 \%$ with $\mathbf{1 b}$ and $96 \%$ with 2 . Imine to enamine ratio, 3:1. All ${ }^{1} \mathrm{H}$ NMR resonances for the imine and enamine matched authentic samples, $\mathbf{4}$ and $\mathbf{5}$. Imine to enamine ratios were $3: 1$.

Table 3, entry 2: Yield, $79 \%$ for $\mathbf{1 b}$ and $74 \%$ for 2 . Imine to enamine ratio, $4: 1 .{ }^{1} \mathrm{H}$ NMR $\left(\mathrm{C}_{6} \mathrm{D}_{5} \mathrm{Cl}, 400\right.$ MHz) $\delta 7.51(\mathrm{~m}, 2 \mathrm{H}, \operatorname{Ar} H), 7.09(\mathrm{~m}, 1 \mathrm{H}, \operatorname{Ar} H), 6.99(\mathrm{~m}, 1 \mathrm{H}, \operatorname{Ar} H), 6.73(\mathrm{~m}, 3 \mathrm{H}, \operatorname{ArH}), 6.53(\mathrm{~m}, 4 \mathrm{H}$, $\operatorname{Ar} H), 6.34(\mathrm{~d}, J=8.0 \mathrm{~Hz}, 2 \mathrm{H}, \operatorname{Ar} H), 6.06(\mathrm{~d}, J=8.0 \mathrm{~Hz}, 1 \mathrm{H}, \operatorname{Ar} H), 5.70(\mathrm{~s}, 0.2 \mathrm{H}$, enamine $H \mathrm{C}(\mathrm{NHPh}))$, $5.17(\mathrm{~s}, 0.2 \mathrm{H}$, enamine $\mathrm{NH}), 3.40\left(\mathrm{~s}, 2 \mathrm{H}\right.$, imine $\left.\mathrm{CH}_{2} \mathrm{Ph}\right), 3.26(\mathrm{~s}, 0.2 \mathrm{H}$, enamine $\mathrm{CHPh}), 1.73(\mathrm{~s}, 3 \mathrm{H}$, imine $\left.\mathrm{CH}_{3}\right), 1.56\left(\mathrm{~s}, 0.6 \mathrm{H}\right.$, enamine $\left.\mathrm{CH}_{3}\right)$.

Table 3, entry 3: Yield, $31 \%$ for $\mathbf{1 b}$ and $72 \%$ for 2 . Imine to enamine ratio, $7: 1 .{ }^{1} \mathrm{H} N M R\left(\mathrm{C}_{6} \mathrm{D}_{5} \mathrm{Cl}, 400\right.$ MHz) $\delta 7.54(\mathrm{~m}, 2 \mathrm{H}, \operatorname{Ar} H), 7.05(\mathrm{~m}, 2 \mathrm{H}, \operatorname{Ar} H), 6.73(\mathrm{~m}, 4 \mathrm{H}, \operatorname{Ar} H), 6.54(\mathrm{~m}, 3 \mathrm{H}, \operatorname{Ar} H), 6.38(\mathrm{~d}, J=8.8$ $\mathrm{Hz}, 2 \mathrm{H}, \operatorname{Ar} H), 6.32(\mathrm{~d}, J=8.8 \mathrm{~Hz}, 1 \mathrm{H}, \operatorname{Ar} H), 5.67$ (s, 0.2H, enamine $H \mathrm{C}(\mathrm{NHPh})), 5.20(\mathrm{~s}, 0.2 \mathrm{H}$, enamine $\mathrm{NH}), 3.59$ (s, 2H, imine $\left.\mathrm{CH}_{2} \mathrm{Ph}\right), 3.40(\mathrm{~s}, 0.2 \mathrm{H}$, enamine $\mathrm{CHPh}), 3.03\left(\mathrm{~s}, 3 \mathrm{H}\right.$, imine $\left.\mathrm{OCH}_{3}\right), 2.92(\mathrm{~s}, 0.6 \mathrm{H}$, enamine $\left.\mathrm{OCH}_{3}\right)$.

Table 3, entry 4: Yield, $>95 \%$ for $\mathbf{1 b}$ and 2. Imine to enamine ratio, 4:1. ${ }^{1} \mathrm{H}$ NMR $\left(\mathrm{C}_{6} \mathrm{D}_{5} \mathrm{Cl}, 400 \mathrm{MHz}\right)$ $\delta 7.47(\mathrm{~m}, 2 \mathrm{H}, \operatorname{ArH}), 7.02(\mathrm{~m}, 1 \mathrm{H}, \operatorname{ArH}), 6.95(\mathrm{~m}, 1 \mathrm{H}, \mathrm{ArH}), 6.91-6.42(\mathrm{~m}, 7 \mathrm{H}, \operatorname{ArH}), 6.19(\mathrm{~d}, J=8.0 \mathrm{~Hz}$, 2H, $\operatorname{Ar} H), 5.91(\mathrm{~d}, J=8.0 \mathrm{~Hz}, 1 \mathrm{H}, \operatorname{ArH}), 5.72(\mathrm{~s}, 0.4 \mathrm{H}$, enamine $H \mathrm{C}(\mathrm{NHPh})), 5.07$ (s, 0.4H, enamine $\mathrm{NH}$ ), 3.44 (s, 2H, imine $\left.\mathrm{CH}_{2} \mathrm{Ph}\right), 3.44$ (s, 0.8H, enamine $\mathrm{CHPh}$ ).

Table 3, entry 5: Yield, $7 \%$ for $\mathbf{1 b}$ and $69 \%$ for $\mathbf{2}$. Only imine was observed. ${ }^{1} \mathrm{H}$ NMR $\left(\mathrm{C}_{6} \mathrm{D}_{5} \mathrm{Cl}, 400\right.$ MHz) $\delta 7.52(\mathrm{~m}, 2 \mathrm{H}, \operatorname{ArH}), 7.06(\mathrm{~m}, 2 \mathrm{H}, \operatorname{ArH}), 7.00-6.35(\mathrm{~m}, 8 \mathrm{H}, \operatorname{Ar} H), 6.21(\mathrm{t}, J=7.6 \mathrm{~Hz}, 1 \mathrm{H}, \operatorname{ArH})$, 3.39 (s, 2H, imine $\left.\mathrm{CH}_{2} \mathrm{Ph}\right), 1.50\left(\mathrm{~s}, 6 \mathrm{H}, \mathrm{CH}_{3}\right)$.

${ }^{1}$ H NMR data for allene hydroamination reactions. Yields were determined by NMR integrations versus an external $\mathrm{CH}_{2} \mathrm{Cl}_{2} / \mathrm{C}_{6} \mathrm{D}_{6}$ standard. 
Allene + 2,6-dimethylaniline: Yield, > 95\%. ${ }^{1} \mathrm{H}$ NMR $\left(\mathrm{C}_{6} \mathrm{D}_{6}, 400 \mathrm{MHz}\right) \delta 7.05(\mathrm{~d}, J=7.2 \mathrm{~Hz}, 2 \mathrm{H}$, $\operatorname{ArH}), 6.96(\mathrm{t}, J=7.2 \mathrm{~Hz}, 1 \mathrm{H}, \mathrm{ArH}), 2.02\left(\mathrm{~s}, 6 \mathrm{H}, \mathrm{CH}_{3}\right), 1.89\left(\mathrm{~s}, 3 \mathrm{H}, \mathrm{CH}_{3}\right), 1.27\left(\mathrm{~s}, 3 \mathrm{H}, \mathrm{CH}_{3}\right)$. These values match those in the literature. ${ }^{6}$

Cyclononadiene + aniline: Yield, $>95 \% .{ }^{1} \mathrm{H}$ NMR $\left(\mathrm{C}_{6} \mathrm{D}_{6}, 400 \mathrm{MHz}\right) \delta 7.09(\mathrm{t}, J=7.6 \mathrm{~Hz}, 2 \mathrm{H}, \mathrm{Ar} H)$, $6.82(\mathrm{t}, J=7.6 \mathrm{~Hz}, 1 \mathrm{H}, \mathrm{ArH}), 6.60(\mathrm{~d}, J=7.6 \mathrm{~Hz}, 2 \mathrm{H}, \mathrm{ArH}), 2.26\left(\mathrm{~m}, 2 \mathrm{H}, \mathrm{CH}_{2}\right), 2.01\left(\mathrm{~m}, 2 \mathrm{H}, \mathrm{CH}_{2}\right), 1.65$ (m, 2H, $\left.\mathrm{CH}_{2}\right), 1.48\left(\mathrm{~m}, 2 \mathrm{H}, \mathrm{CH}_{2}\right), 1.41-0.98\left(\mathrm{~m}, 8 \mathrm{H}, \mathrm{CH}_{2}\right)$. These values are analogous to those in the literature for cyclononylidene-(2,6-dimethylphenyl)amine: ${ }^{1} \mathrm{H} \mathrm{NMR}\left(\mathrm{C}_{6} \mathrm{D}_{6}, 300 \mathrm{MHz}\right) \delta 6.99(\mathrm{~d}, J=7.6$ $\mathrm{Hz}, 2 \mathrm{H}, \mathrm{ArH}), 6.86(\mathrm{t}, J=7.2,1 \mathrm{H}, \mathrm{ArH}), 2.62\left(\mathrm{~m}, 2 \mathrm{H}, \mathrm{CH}_{2}\right), 2.11\left(\mathrm{~m}, 2 \mathrm{H}, \mathrm{CH}_{2}\right), 2.07\left(\mathrm{~s}, 6 \mathrm{H}, \mathrm{CH}_{3}\right), 1.97$ (m, 2H, $\left.\mathrm{CH}_{2}\right), 1.68\left(\mathrm{~m}, 2 \mathrm{H}, \mathrm{CH}_{2}\right), 1.68-1.48\left(\mathrm{~m}, 8 \mathrm{H}, \mathrm{CH}_{2}\right){ }^{7}$

General procedures for hydrolysis of imines. For compounds in Table 2, the solutions from NMR tube reactions were diluted with $3 \mathrm{~mL}$ of $\mathrm{Et}_{2} \mathrm{O}$, mixed with $3 \mathrm{~mL}$ of a $10 \%$ solution of $\mathrm{HCl}$ in water and allowed to stir for at least $4 \mathrm{~h}$. The ethereal and aqueous layers were then separated and the aqueous layer was extracted with $3 \times 2 \mathrm{~mL}$ of $\mathrm{Et}_{2} \mathrm{O}$. The combined $\mathrm{Et}_{2} \mathrm{O}$ portions were dried over $\mathrm{MgSO}_{4}$ and filtered. The resulting solutions were analyzed by GC-MS and compared to commercially-available authentic samples of the respective ketones by co-injection to confirm ketone identity. Trimethyoxybenzene was used as an internal standard for GC-MS yields.

Table 2, entry 1: Yield, 74\%. Retention time of 3-hexanone, $7.83 \mathrm{~min}$. Retention time of product, $7.83 \mathrm{~min}$.

Table 2, entry 2: Yield, 72\%. Retention time of 2-hexanone, $7.91 \mathrm{~min}$. Retention time of products, 7.83 and 7.91.

Table 2, entry 3: Yield, 47\%. Retention time of acetophenone, $12.78 \mathrm{~min}$. Retention time of product, 12.78 .

Table 2 entry 4: Yield, 40\%. Retention time of 1-pentyne, $6.23 \mathrm{~min}$. Retention time of product, 6.23.

7 Johnson, J. S.; Bergman, R. G. J. Am. Chem. Soc. 2001, 123, 2923-2924. 
For compounds in Table 3, larger scale reactions were diluted with $20 \mathrm{~mL}$ of $\mathrm{CH}_{2} \mathrm{Cl}_{2}$, mixed with $50 \mathrm{~mL}$ of a $10 \%$ solution of $\mathrm{HCl}$ in water and allowed to stir for at least $4 \mathrm{~h}$. The organic and aqueous layers were then separated. The aqueous layer was then extracted with $3 \times 10 \mathrm{~mL}$ of $\mathrm{CH}_{2} \mathrm{Cl}_{2}$. The combined $\mathrm{CH}_{2} \mathrm{Cl}_{2}$ portions were dried over $\mathrm{MgSO}_{4}$ and filtered. Solvent was removed under vacuum to give a yellow solid that was purified by flash chromatography $\left(10 \% \mathrm{Et}_{2} \mathrm{O}\right.$ in pentane). The ${ }^{1} \mathrm{H}$ NMR spectra of all hydrolysis products from compounds in Table 3 matched those of commercially available deoxybenzoin. ${ }^{1} \mathrm{H}$ NMR $\left(\mathrm{C}_{6} \mathrm{D}_{6}, 400 \mathrm{MHz}\right) \delta 7.86(\mathrm{~m}, 2 \mathrm{H}, \operatorname{Ar} H), 7.12-6.90(\mathrm{~m}, 8 \mathrm{H}, \operatorname{Ar} H), 3.86(\mathrm{~s}, 2 \mathrm{H}$, $\mathrm{CH}_{2}$ ). The isolated yields for entries 1,3 , and 4 are given below.

Entry 1: Diphenylacetylene $(111 \mathrm{mg}, 0.624 \mathrm{mmol})$. Aniline $(58 \mathrm{mg}, 0.624 \mathrm{mmol})$. Deoxybenzoin (92 $\mathrm{mg}, 0.47 \mathrm{mmol}, 75 \%)$.

Entry 3: Diphenylacetylene $(158 \mathrm{mg}, 0.886 \mathrm{mmol})$. Anisidine $(109 \mathrm{mg}, 0.886 \mathrm{mmol})$. Deoxybenzoin (145 mg, $0.738 \mathrm{mmol}, 83 \%)$.

Entry 4: Diphenylacetylene (190 mg, $1.07 \mathrm{mmol})$. p-Chloroaniline (136 mg, $1.07 \mathrm{mmol})$. Deoxybenzoin (134 mg, $0.682 \mathrm{mmol}, 64 \%)$.

Representative procedure for the reduction of imines in Table 2. Hydroamination reaction mixtures $(0.86 \mathrm{mmol}$ of substrate in $3 \mathrm{~mL}$ of benzene) were transferred directly into a Schlenk flask containing $\mathrm{LiAlH}_{4}(1.72 \mathrm{mmol})$ and THF $(20 \mathrm{~mL})$. The flask was fitted with a condenser and heated to 65 ${ }^{\circ} \mathrm{C}$ for $8 \mathrm{~h}$. The flask was allowed to cool and then poured into $40 \mathrm{~mL}$ of water cooled with an ice water bath. This mixture was stirred while $50 \mathrm{~mL}$ of $\mathrm{CH}_{2} \mathrm{Cl}_{2}$ and $40 \mathrm{~mL}$ of $2 \mathrm{M} \mathrm{KOH}$ were added. This mixture was allowed to stir for an additional $30 \mathrm{~min}$. The organic layer was separated and then the aqueous layer was extracted with $3 \times 20 \mathrm{~mL}$ of $\mathrm{CH}_{2} \mathrm{Cl}_{2}$. The combined organic portions were dried over $\mathrm{MgSO}_{4}$ and filtered. Solvent was removed under vacuum to give a yellow oil which was purified by flash chromatography $\left(10 \% \mathrm{Et}_{2} \mathrm{O}\right.$ in pentane).

Table 2, entry 1: 3-Hexyne (121 mg, $1.47 \mathrm{mmol})$. Aniline (137 mg, $1.47 \mathrm{mmol})$. Amine (216 mg, $1.22 \mathrm{mmol}, 83 \%)$. ${ }^{1} \mathrm{H} \mathrm{NMR}\left(\mathrm{CDCl}_{3}, 400 \mathrm{MHz}\right) \delta 7.28(\mathrm{t}, J=8 \mathrm{~Hz}, 2 \mathrm{H}, \mathrm{ArH}), 6.78(\mathrm{t}, J=6.8 \mathrm{~Hz}, 1 \mathrm{H}$, $\operatorname{Ar} H$ ), 3.5 (b, 1H, NH), 3.43 (quin, $J=5.6 \mathrm{~Hz}, 1 \mathrm{H}, \mathrm{CH}$ ), 1.77-1.48 (m, 6H, $\mathrm{CH}_{2}$ ), 1.06 (t, $J=7.2 \mathrm{~Hz}, 6 \mathrm{H}$, $\mathrm{CH}_{3}$ ). These values match those in the literature. ${ }^{8}$ 
Table 2, entry 3: Phenylacetylene ( $92 \mathrm{mg}, 0.90 \mathrm{mmol})$. Aniline ( $84 \mathrm{mg}, 0.90 \mathrm{mmol})$. Amine (114 mg, $0.58 \mathrm{mmol}, 64 \%) .{ }^{1} \mathrm{H}$ NMR $\left(\mathrm{CDCl}_{3}, 400 \mathrm{MHz}\right) \delta 7.75-7.63(\mathrm{~m}, 4 \mathrm{H}, \mathrm{Ar} H), 7.51(\mathrm{~m}, 1 \mathrm{H}, \mathrm{Ar} H), 6.90(\mathrm{t}, J=$ $7.6 \mathrm{~Hz}, 1 \mathrm{H}, \operatorname{Ar} H), 6.67(\mathrm{~d}, J=7.6 \mathrm{~Hz}, 2 \mathrm{H}, \operatorname{Ar} H), 4.63(\mathrm{q}, J=6.8 \mathrm{~Hz}, 1 \mathrm{H}, \mathrm{CH}), 1.65(\mathrm{~d}, J=6.8 \mathrm{~Hz}, 3 \mathrm{H}$, $\mathrm{CH}_{3}$ ). These values match those in the literature. ${ }^{8}$

Hydroamination of norbornene with aniline. In the glovebox a vial was charged with $28 \mathrm{mg}$ of $1 \mathrm{a}$ (0.054 mmol, 1 equiv) and $3 \mathrm{~mL}$ of benzene. The resulting solution was mixed with $101 \mathrm{mg}$ of norbornene (1.07 mmol, 20 equiv), $49 \mathrm{mg}$ of $\mathrm{Ph}_{3} \mathrm{CB}\left(\mathrm{C}_{6} \mathrm{~F}_{5}\right)_{4}(0.054 \mathrm{mmol}, 1$ equiv) and $199 \mathrm{mg}$ of aniline ( $2.14 \mathrm{mmol}, 40$ equiv) in the order given. The reaction mixture was then transferred to a Schlenk flask with a Teflon stopper, taken out of the glovebox and placed in a $135{ }^{\circ} \mathrm{C}$ bath for $24 \mathrm{~h}$. The reaction was allowed to cool and then transferred to a flask and diluted with $40 \mathrm{~mL}$ of $\mathrm{CH}_{2} \mathrm{Cl}_{2}$ at which point a flocculent precipitate was observed. The solution was filtered and then solvent was removed under vacuum. Compounds $\mathbf{1 0}$ and $\mathbf{1 1}$ were separated and purified by flash chromatography (3-20\% gradient, $\mathrm{Et}_{2} \mathrm{O} /$ pentane). Combined yield $32 \%(10 \% \mathbf{1 0}, 22 \% 11)$. ${ }^{1} \mathrm{H} \mathrm{NMR}$ of compound $\mathbf{1 0}\left(\mathrm{CDCl}_{3}\right.$, $400 \mathrm{MHz}) \delta 7.17(\mathrm{t}, J=7.6 \mathrm{~Hz}, 2 \mathrm{H}, H 9), 6.69(\mathrm{t}, J=7.2 \mathrm{~Hz}, 1 \mathrm{H}, H 10), 6.59$ (d, $J=7.6 \mathrm{~Hz}, 2 \mathrm{H}, H 8), 3.7(\mathrm{~b}, 1 \mathrm{H}, \mathrm{NH}), 3.23(\mathrm{dd}, J=7.6,2.8 \mathrm{~Hz}, 1 \mathrm{H}, H 1)$, 2.29 (s, 2H, H3,H6), 1.82 (ddd, $J=2.4,7.6,12.8 \mathrm{~Hz}, 1 \mathrm{H}, H 2$ endo), 1.57 $1.13(\mathrm{~m}, 7 \mathrm{H}, H 7, H 5, H 4, H 2 \mathrm{exo}) .{ }^{1} \mathrm{H}$ NMR C-bound $\left(\mathrm{C}_{6} \mathrm{D}_{6}, 400 \mathrm{MHz}\right) \delta$

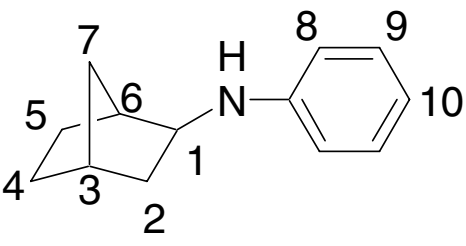
Compound 10

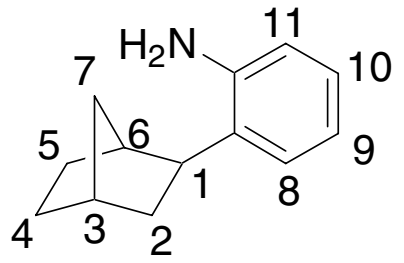

Compound 11 $7.17(\mathrm{~d}, J=7.6 \mathrm{~Hz}, 1 \mathrm{H}, H 8), 7.09$ (t, $J=7.6 \mathrm{~Hz}, 1 \mathrm{H}, H 10), 6.79$ (t, $J=7.6$ $\mathrm{Hz}, 1 \mathrm{H}, H 9), 6.71$ (d, $J=7.6,1 \mathrm{H}, H 11), 3.7$ (b, 2H, NH$), 2.61$ (m, 2H, H1, H6), 2.51 (s, 1H, H3), 1.731.57 (m, 5H, $H 2$ exo, $H 2$ endo, $H 4$ exo, $H 5$ exo, $H 7$ syn), 1.42-1.24 (m, 2H, $H 4$ endo, $H 5$ endo), 1.05 (d, J $=9.6 \mathrm{~Hz}, 1 \mathrm{H}, H 7$ anti). Both sets of NMR resonances match literature values. ${ }^{9}$

8 Bytschkov, I.; Doye, S. Eur. J. Org. Chem. 2001, 23, 4411-4418.

9 Brunet, J.-J.; Commenges, G.; Neibecker, D.; Philippot, K. J. Organomet. Chem. 1994, 469, 221228. 
Stoichiometric addition of 2,6-dimethylaniline to compound 3. In the glovebox, a vial was charged with $42 \mathrm{mg}\left(0.033 \mathrm{mmol}, 1\right.$ equiv) of 3 and $0.5 \mathrm{~mL}$ of $\mathrm{C}_{6} \mathrm{D}_{5} \mathrm{Cl}$. The resulting solution was mixed with $4 \mathrm{mg}$ ( $0.033 \mathrm{mmol}, 1$ equiv) of 2,6-dimethylaniline and then transferred to an NMR tube. The ${ }^{1} \mathrm{H}$ NMR spectrum of this mixture showed that the 2,6-dimethylaniline had coordinated to the metallacycle to give complex 12. ${ }^{1} \mathrm{H}$ NMR $\left(\mathrm{C}_{6} \mathrm{D}_{5} \mathrm{Cl}, 500 \mathrm{MHz}\right) \delta 7.24-6.65(\mathrm{~m}, 23 \mathrm{H}, \mathrm{Ar} H), 4.17(\mathrm{~d}, J=15 \mathrm{~Hz}, 1 \mathrm{H}$, CHHPh), 3.88 (d, $J=15 \mathrm{~Hz}, 1 \mathrm{H}, \mathrm{CHHPh}), 3.73$ (d, $J=10 \mathrm{~Hz}, 1 \mathrm{H}, \mathrm{CHHPh}), 2.45\left(\mathrm{~s}, 6 \mathrm{H}, \mathrm{CH}_{3}\right), 1.43$ (d, $J$ $=10 \mathrm{~Hz}, 1 \mathrm{H}, \mathrm{CHHPh}), 0.20\left(\mathrm{~s}, 9 \mathrm{H}, \mathrm{CMe}_{3}\right),-1.05(\mathrm{~d}, J=15 \mathrm{~Hz}, \mathrm{NH}),-1.23(\mathrm{~d}, J=15 \mathrm{~Hz}, \mathrm{~N} H)$. The reaction mixture was allowed to sit at $25{ }^{\circ} \mathrm{C}$ for $24 \mathrm{~h}$. A second NMR spectrum showed that the diastereotopic $\mathrm{NH}$ resonances had disappeared. The same experiment was repeated with $85 \%$ deuterated 2,6-dimethylaniline- $d_{2}$. The ${ }^{1} \mathrm{H}$ NMR spectrum of the initial reaction mixture was identical to that of $\mathbf{1 2}$ except for the integrations of the NH resonances which were only $0.2 \mathrm{H} . \quad \mathrm{A}^{2} \mathrm{H}$ NMR spectrum of this reaction mixture $\left(\mathrm{C}_{6} \mathrm{~F}_{5} \mathrm{Cl}, 500 \mathrm{MHz}\right)$ contained a broad peak at $-0.98 \mathrm{ppm}$. This reaction was also allowed to sit at $25{ }^{\circ} \mathrm{C}$ for $24 \mathrm{~h}$ and NMR analysis also showed disappearance of the diastereotopic ND resonances. 